Article

\title{
Empirical Model of Human Thermal Comfort in Subtropical Climates: A First Approach to the Brazilian Subtropical Index (BSI)
}

\author{
João Paulo Assis Gobo ${ }^{1, *(\mathbb{C},}$, Marlon Resende Faria ${ }^{2}{ }^{\mathbb{D}}$, Emerson Galvani ${ }^{1}{ }^{\mathbb{D}}$, \\ Fabio Luiz Teixeira Goncalves ${ }^{3}$ and Leonardo Marques Monteiro ${ }^{4}$ (D) \\ 1 Faculty of Philosophy, Literature and Humanities (FFLCH), University of São Paulo (USP), \\ São Paulo 05508-080, Brazil; egalvani@usp.br \\ 2 Institute of Physics (IF), University of São Paulo (USP), São Paulo 05508-090, Brazil; marlon.faria@usp.br \\ 3 Institute of Astronomy, Geophysics and Atmospheric Sciences (IAG), University of São Paulo (USP), \\ São Paulo 05508-090, Brazil; fabio.goncalves@iag.usp.br \\ 4 School of Architecture and Urbanism (FAU), University of São Paulo (USP), São Paulo 05508-080, Brazil; \\ leo4mm@usp.br \\ * Correspondence: jpgobo@usp.br; Tel.: +55-11-999664168
}

Received: 13 September 2018; Accepted: 2 October 2018; Published: 8 October 2018

\begin{abstract}
The bioclimatic well-being of individuals is associated with the environmental characteristics of where they live. Knowing the relationships between local and regional climatic variables as well as the physical characteristics of a given region and their implications on thermal comfort is important for identifying aspects of thermal sensation in the population. The aim of this study is to develop an empirical model of human thermal comfort based on subjective and individual environmental patterns observed in the city of Santa Maria, located in the state of Rio Grande do Sul, Brazil (Subtropical climate). Meteorological data were collected by means of an automatic meteorological station installed in the city center, which contained sensors measuring global solar radiation, air temperature, globe temperature (via a grey globe thermometer), relative humidity and wind speed and direction. A total of 1720 people were also interviewed using a questionnaire adapted from the model recommended by ISO 10551. Linear regressions were performed to obtain the predictive model. The observed results proposed a new empirical model for subtropical climate, the Brazilian Subtropical Index (BSI), which was verified to be more than $79 \%$ accurate, with a coefficient of determination of 0.926 and an adjusted $R^{2}$ value of 0.924 .
\end{abstract}

Keywords: thermal comfort index; linear regression; predictive model

\section{Introduction}

Human thermal comfort ranges have been established or adapted in the last few years from a thermal sensitivity scale of seven or nine points for the evaluation of the average perception of people regarding weather conditions in open spaces [1-6]. New ways to predict the thermal sensations of people in their typical environments, based on personal, environmental and physiological variables, have been explored for decades [7]. Accordingly, mathematical models that predict the thermal responses of individuals in their natural environments have been developed [7-10].

These studies have been developed for the determination of thermal comfort in open spaces under uncontrolled thermal conditions [2-4,11,12] and use modelling and evaluation methods from a thermophysiological perspective. Examples include the studies of Gulyás et al. [13] and Höppe [1], while others are based on the perspective of the relationships between the climatic parameters that determine the level of thermal comfort of humans in open spaces [14,15]. 
To assess the thermal comfort and sensation patterns of the population during the different seasons of the year, for temperate climates [5,6,16-19], or hot and humid climates [20-23], many studies have attempted to predict comfort conditions by calibrating the interpretive ranges of different indices to the climatic and thermal perception conditions of certain places.

Studies show differences in outdoor thermal comfort between distinct climatic zones $[24,25]$ and suggest a need for additional field surveys on subjective human perception in those environments [22].

However, the calibration of the thermal comfort ranges of a given index does not always answer all of the questions raised about the thermal comfort of a given location. Thus, the determination of a predictive model based on the environmental, physiological, and subjective aspects of the reference environment offers a solution for better interpretations of the biometeorological aspects of the place of study [24].

Several indices used to evaluate outdoor thermal comfort were originally developed for indoor spaces [26,27]. Some examples are the Standard Effective Temperature (SET) index [28], which was adapted as OUT_SET [29] for outdoor environments, and the Predicted Mean Vote (PMV) [30], the use of which is suggested by [31] and by [32], adapted for outdoor environments and taking into account the influence of shortwave radiation.

Thus, according to Salata et al. [33], one of the main solutions found for considering the influence of personal adaptions and expectations of the population of a certain place on thermal sensation is the proposal of an empirical index based on multiple regression analyses [8-10,33]. The correlation of multiple variables is commonly performed by means of linear regression similar to many previous studies [6,8-10,34-36], and the resulting groups of indices define human comfort as a function of the thermal environment. These indices are suitable for long term studies such as historical bioclimatic analyses [37].

Empirical indices accurately describe the thermal sensations of pedestrians and the environmental factors that most affect their thermal behavior [38]. These indices are adequate for the cities in which they were analyzed, whereas the simplified models are suitable for large-scale studies in which urban microclimates can be neglected [37,38].

A wide variety of studies have been conducted in temperate and subtropical countries [5,6,16-18,24,39-42], each of which are characterized by specific climatic and cultural conditions, using a cross-sectional approach. However, there is a lack of research on thermal comfort in subtropical climates, which are characteristic of the geographic areas South of the Tropic of Capricorn and North of the Tropic of Cancer [43,44], especially in the Brazilian subtropical climate zone.

The present study proposes a definition for a new simplified empirical index based on cross-sectional interviews and on meteorological data, including air temperature, relative air humidity, and wind speed, observed simultaneously to the interviews through multiple linear regressions in the city of Santa Maria, state of Rio Grande do Sul, Brazil. This is a subtropical climate region, classified as Cfa according to Alvares et al. [44] and Koppen [45]. However, the objective of this study is not to propose a global index with a wide application, but to pave the way for future studies that promote the improvement and adjustment of this model in order to meet a wider application demand in subtropical regions.

\section{Experiments}

The meteorological and thermal sensation data were collected during 2015 and 2016 in the city of Santa Maria, Rio Grande do Sul, Brazil, which is located in the geographic center of the state and has an estimated population of 278,445 inhabitants [46]. According to Köppen [45], in terms of general climatic classification, the city is classified as type $\mathrm{Cfa}$, with a hot and rainy temperate climate, no dry season, and a hot summer. The hottest month has a mean temperature higher than $22^{\circ} \mathrm{C}$ and a mean air temperature in the hottest four months above $10^{\circ} \mathrm{C}$, and the coldest month has a mean temperature above $3{ }^{\circ} \mathrm{C}$. 
For this purpose, a Campbell CR100 Automatic Weather Station (AWS) was used, at a maximum height of $2.0 \mathrm{~m}$, with a mobile aluminum tripod containing the following sensors (Table 1):

Table 1. Sensor model and resolution.

\begin{tabular}{cc}
\hline Sensor Model & Resolution \\
\hline Rain gage model TE525 Tipping Bucket Rain Gage & $0.10 \mathrm{~mm}$ \\
Global radiation sensor model LI200X Pyranometer & $0.2 \mathrm{~kW} \cdot \mathrm{m}^{-2}$ \\
Temperature and humidity sensor model HMP35C Temperature and Relative Humidity Probe & $0.1^{\circ} \mathrm{C}$ and $0.6 \%$ \\
Speed and wind direction sensor models 03001 R.M. Young Wind Setry Set 03101 R.M. Young & $0.5 \mathrm{~m} \cdot \mathrm{s}^{-1}$ and $5^{\circ}$ \\
Wind Sentry Anemometer 03301 R. M. Young Wind Sentry Vane & $0.03{ }^{\circ} \mathrm{C}$ \\
TMCx-HD gray globe thermometer & \\
\hline
\end{tabular}

Primary data on air temperature, gray globe temperature-because the station was set up in an open space exposed to direct solar radiation [47]—relative humidity, wind speed, wind gusts, global solar radiation, and rain were collected. The station was positioned in a paved area in the center of Santa Maria (Figure 1).

Field data collection was performed during the following periods: 5-7 August 2015, 17-19 January 2016, and 6-8 July 2016. These periods were selected as representative of summer (January 2016) and winter (July 2016). The period of August 2015 was used for the validation of the data.

The choice of the representative periods of summer and winter was aimed at demonstrating the seasonality of the data and evaluating its influence on the final results. The objective is to incorporate the region's climatic amplitudes into the proposed models, because methodological and operational evaluations are not necessarily possible over the course of the entire year. The seasonal aspect is incorporated into the model to make observations in representative periods of summer and winter. Collection of meteorological data and interviews with the local population were performed from 9:00 a.m. to 5:00 p.m. local time during the field experiments described above. The model can also be applied to the night period, simply by including the input variables of this period. However, it is understood that the flow of people in this environmental profile is greater in the daytime and in the early hours of dusk.

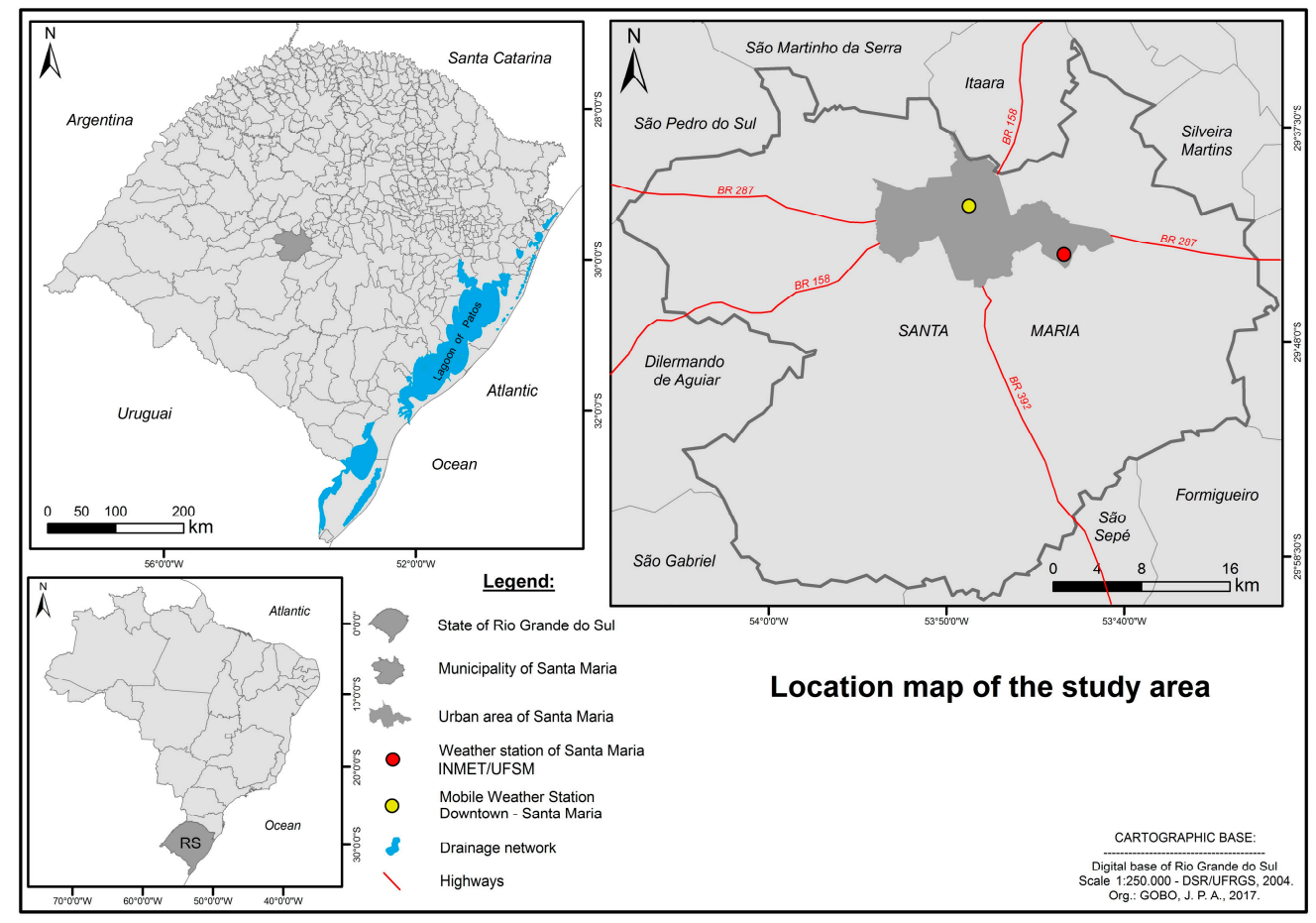

(a)

Figure 1. Cont. 


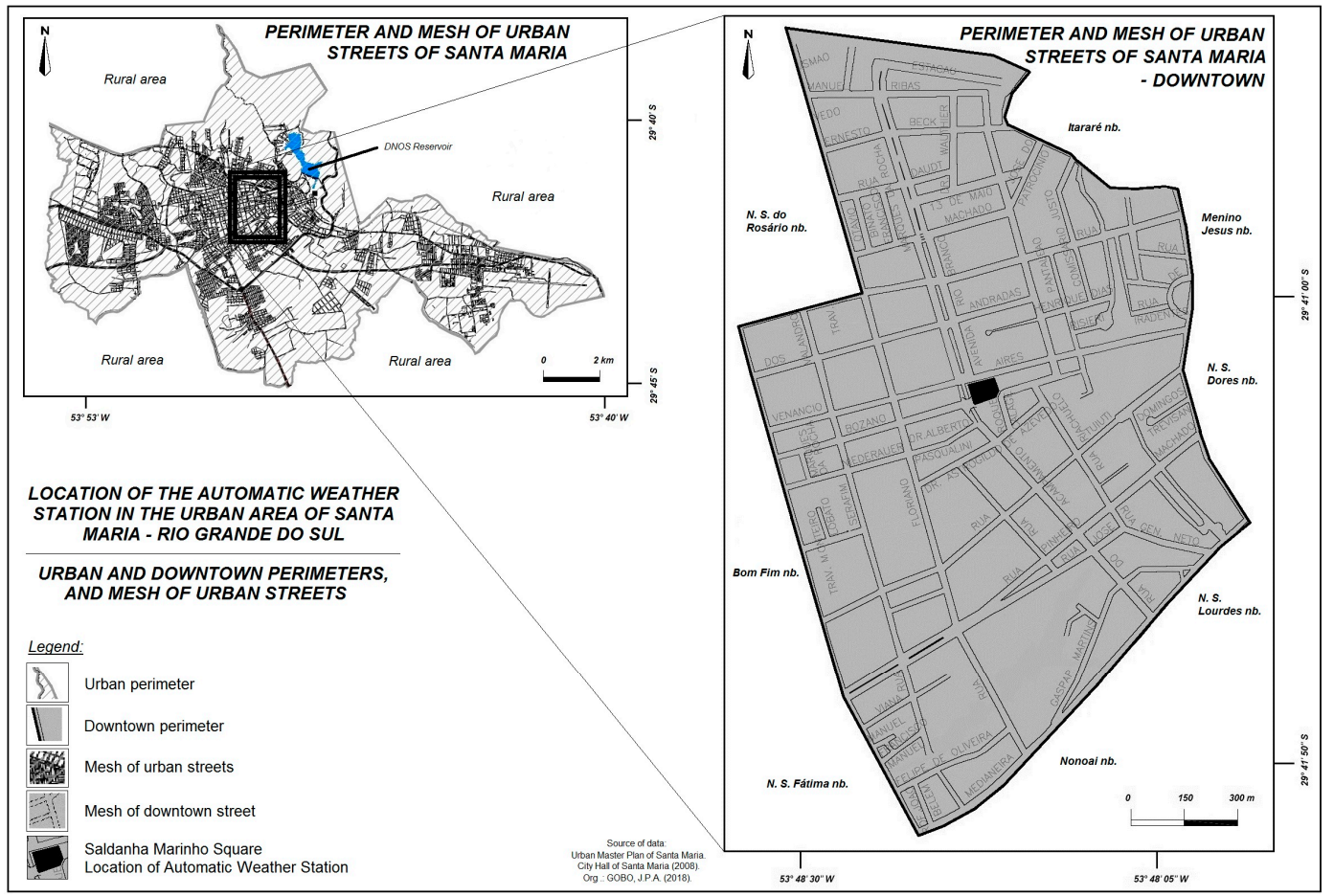

(b)

Figure 1. Location of the study area (a) and of the automatic weather station (b).

On the days of field research, the 5-7 August 2015, period was characterized by a persistent high-pressure system anomaly (anticyclone positioned at approximately 30 degrees of latitude), with relatively slow displacement of high pressures, which persisted for several days. During the January 2016 field research days, it was possible to identify a pattern compatible with Santa Maria's normal climatological averages for that month, which presented high temperatures with maxima above $32{ }^{\circ} \mathrm{C}$. In the analysis of the next winter, during July 2016, above-average temperatures for Santa Maria were observed mainly in the first day of analysis, but after that day, temperatures were within the range expected for that season.

The mean temperature and relative humidity patterns observed in all periods of data collection are shown in Figure 2. The patterns of average velocity and maximum wind speed are observed in Figure 3 and the predominant direction of wind for the period of analysis is shown in Figure 4.

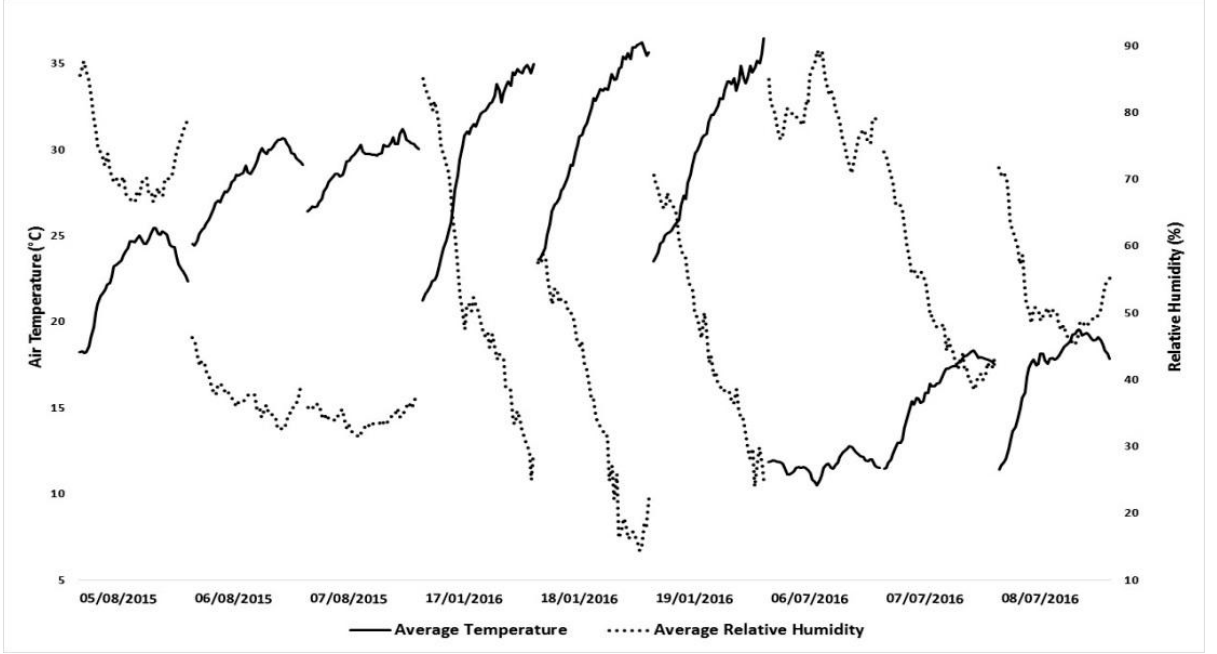

Figure 2. Mean air temperature and relative air humidity for the period of analysis. 


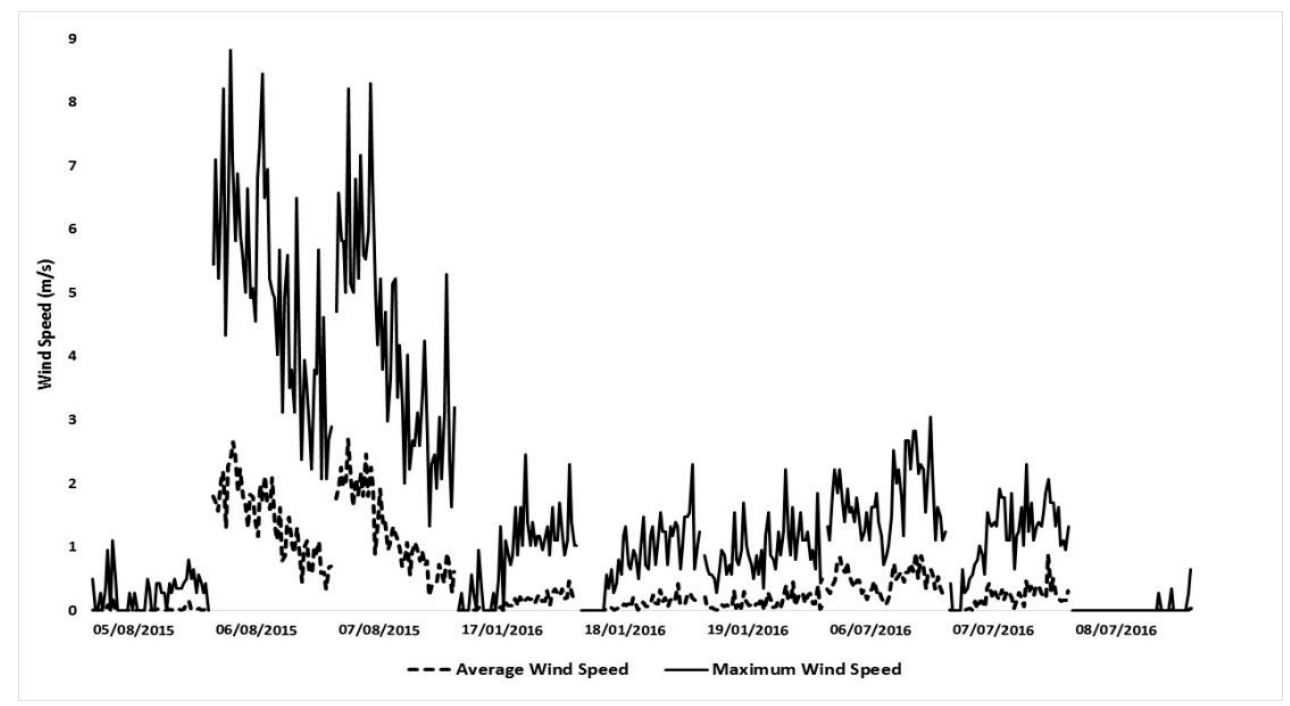

Figure 3. Patterns of average velocity and maximum wind speed for the period of analysis.
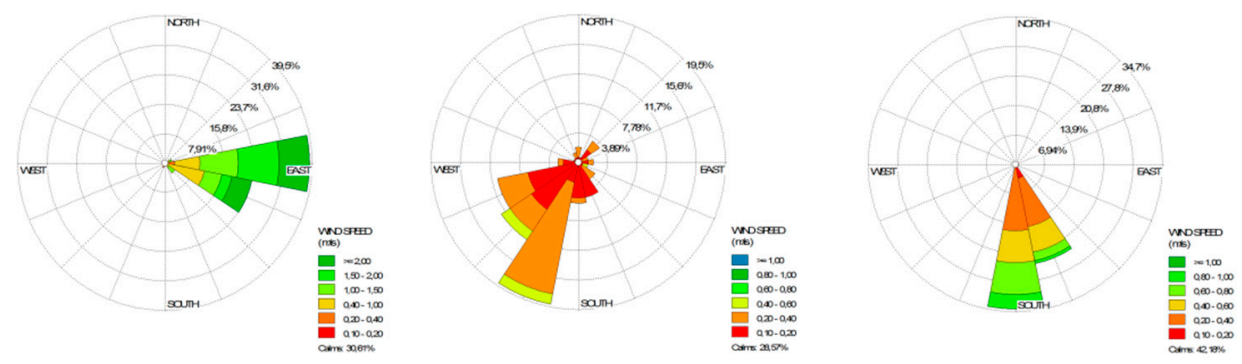

Figure 4. Predominant direction of wind for the period of analysis.

The mean patterns of the main climatic attributes observed in the field are shown in Table 2.

Table 2. Average values of climatic attributes collected during the periods of analysis.

\begin{tabular}{ccccccccc}
\hline Days & $\begin{array}{c}\text { Average } \\
\text { Temperature } \\
\left({ }^{\circ} \mathbf{C}\right)\end{array}$ & $\begin{array}{c}\text { Minimum } \\
\text { Temperature } \\
\left({ }^{\circ} \mathbf{C}\right)\end{array}$ & $\begin{array}{c}\text { Maximum } \\
\text { Temperature } \\
\left({ }^{\circ} \mathbf{C}\right)\end{array}$ & $\begin{array}{c}\text { Average } \\
\text { Relative } \\
\text { Humidity }(\%)\end{array}$ & $\begin{array}{c}\text { Minimum } \\
\text { Relative } \\
\text { Humidity (\%) }\end{array}$ & $\begin{array}{c}\text { Maximum } \\
\text { Relative } \\
\text { Humidity }(\%)\end{array}$ & $\begin{array}{c}\text { Average } \\
\text { Wind Speed } \\
(\mathbf{m} / \mathbf{s})\end{array}$ & $\begin{array}{c}\text { Maximum } \\
\text { Wind Speed } \\
(\mathbf{m} / \mathbf{s})\end{array}$ \\
\hline 5 August 2015 & 22.9 & 18.0 & 25.7 & 73.1 & 65.0 & 88.2 & 0.0 \\
6 August 2015 & 28.4 & 24.4 & 30.7 & 37.6 & 32.0 & 47.2 & 1.4 \\
7 August 2015 & 29.3 & 26.4 & 31.4 & 34.4 & 30.9 & 38.2 & 1.3 \\
17 January 2016 & 30.0 & 21.1 & 35.2 & 52.7 & 23.9 & 86.7 & 0.1 \\
18 January 2016 & 31.5 & 23.6 & 36.6 & 36.3 & 11.4 & 59.8 & 0.1 \\
19 January 2016 & 30.5 & 23.5 & 36.7 & 46.9 & 23.6 & 70.8 & 0.1 \\
6 July 2016 & 10.5 & 8.1 & 12.9 & 79.7 & 70.3 & 89.8 & 0.3 \\
7 July 2016 & 16.0 & 11.4 & 18.4 & 51.2 & 38.5 & 74.3 & 2.3 \\
8 July 2016 & 17.2 & 11.3 & 19.7 & 52.9 & 44.1 & 71.9 & 0.2 \\
\hline
\end{tabular}

In the present study, only those individuals who had resided in the town for more than one year were interviewed to derive a function of the individual thermal history and environmental memory, as observed by Nikolopoulou et al. [48], in a total of 1720 interviews (Table 3). Interviewees also had to exhibit 0.3 to 1.5 clo of clothing insulation, which corresponds to wearing jeans and T-shirt or a suit [49], and $300 \mathrm{~W}$ of physical activity, because only people in motion (walking) were included [50]. The questionnaire used was an adaptation of the one included in the standard ISO 10551 (1995) (Figure 5). 
Table 3. Description of the analyzed population.

\begin{tabular}{|c|c|c|c|c|c|}
\hline Days of Analysis & Gender & $\mathbf{N}$ & Average Age (Years) & Average Weight (Kg) & Average Height (m) \\
\hline \multirow{2}{*}{5 August 2015} & $\mathrm{~F}$ & 159 & 33 & 62.90 & 1.630 \\
\hline & M & 128 & 35 & 78.00 & 1.745 \\
\hline Total & & 287 & 34 & 69.63 & 1.681 \\
\hline \multirow{2}{*}{6 August 2015} & $\mathrm{~F}$ & 146 & 31 & 62.97 & 1.639 \\
\hline & M & 136 & 34 & 76.75 & 1.742 \\
\hline Total & & 282 & 32 & 69.61 & 1.688 \\
\hline \multirow{2}{*}{7 August 2015} & $\mathrm{~F}$ & 149 & 31 & 63.30 & 1.641 \\
\hline & M & 139 & 32 & 77.23 & 1.755 \\
\hline Total & & 288 & 32 & 70.02 & 1.696 \\
\hline \multirow{2}{*}{17 January 2016} & $\mathrm{~F}$ & 63 & 30 & 65.00 & 1.640 \\
\hline & M & 81 & 37 & 75.20 & 1.722 \\
\hline Total & & 144 & 34 & 70.74 & 1.686 \\
\hline \multirow{2}{*}{18 January 2016} & $\mathrm{~F}$ & 81 & 34 & 64.64 & 1.642 \\
\hline & M & 63 & 33 & 81.30 & 1.766 \\
\hline Total & & 144 & 33 & 71.93 & 1.696 \\
\hline \multirow{2}{*}{19 January 2016} & $\mathrm{~F}$ & 85 & 30 & 64.00 & 1.644 \\
\hline & M & 59 & 33 & 79.20 & 1.743 \\
\hline Total & & 144 & 31 & 70.23 & 1.685 \\
\hline \multirow{2}{*}{6 July 2016} & $\mathrm{~F}$ & 72 & 35 & 65.54 & 1.618 \\
\hline & M & 72 & 32 & 77.10 & 1.745 \\
\hline Total & & 144 & 34 & 71.32 & 1.681 \\
\hline \multirow{2}{*}{7 July 2016} & $\mathrm{~F}$ & 89 & 33 & 69.70 & 1.641 \\
\hline & M & 54 & 33 & 79.61 & 1.751 \\
\hline Total & & 143 & 33 & 73.44 & 1.683 \\
\hline \multirow{2}{*}{8 July 2016} & $\mathrm{~F}$ & 92 & 33 & 68.12 & 1.648 \\
\hline & M & 52 & 36 & 78.52 & 1.747 \\
\hline Total & & 144 & 35 & 71.88 & 1.684 \\
\hline Grand Total & & 1720 & 33 & 70.68 & 1.687 \\
\hline
\end{tabular}

Data of the interviewee:

age (_-

Sex: (_) M (_ $)$ F

Weight (__

Height (_

With regard to the individual's dress, he is wearing:

$0,3 \operatorname{clo}(\ldots) ; 0,5 \operatorname{clo}(\ldots) ; 0,8 \operatorname{clo}\left(\_\right) ; 1,0$ clo (__ $) ; 1,5$ clo (__

1. At this very moment, I'm feeling:

( ) Cold -3

() Cool -2

() Slightly cool -1

() Neither cold nor hot 0

() Slightly warm 1

() Warm 2

( ) Hot 3

2. At this very moment, regarding the weather, I am:

() comfortable 0

() a little uncomfortable 1

( ) uncomfortable 2

() very uncomfortable 3

3. Right now, I'd rather be feeling:

() Much colder -3

() Colder -2

( ) A little more cold -1

( ) No changes 0

( ) A little more heat 1

() More heat 2

( ) Much more heat 3
4. With regard to air temperature, I would prefer it to be:

() lowest -1

( ) as is 0

() highest 1

() I do not know how to say $X$.

5. With regard to air humidity, I would prefer the air to be:

( ) drier -1

( ) as is 0

() wettest 1

() I do not know how to say $X$.

6. Regarding the wind, I would prefer it to be:

() weaker -1

( ) as is 0

() stronger 1

( ) I do not know how to say $X$.

7. With regard to solar radiation, I would prefer it to be:

() softer -1

( ) as is 0

() more intense 1

( ) I can not say X.

Figure 5. The questionnaire adapted from ISO 10551 (1995). 
From the correlation between the environmental variables (air temperature, relative air humidity and wind speed) observed in the field and the subjective answers, a new empirical index was proposed. Only the data referring to the collection days in January and July 2016 were used because the August 2015 data were later used to validate the results of the index by means of an uncertainty test for the samples and a Student's $t$-test.

All statistical procedures were performed using the statistical software $\mathrm{R}$, and the multiple linear regression method is described by the following mathematical expression:

$$
Y=\alpha_{1} \cdot x_{1}+\alpha_{2} \cdot x_{2}+\alpha_{3} \cdot x_{3}+\cdots \alpha_{n} \cdot x_{n}+c
$$

where $n$ is the number of terms in the equation, $\alpha_{n}$ are the parameters (constants) obtained by the regression, $c$ is the constant that corresponds to the point where the adjusted line intersects the $y$-axis, $Y$ is the dependent variable, and $x_{n}$ are the independent variables.

In the present study, what we call the mean index is, in fact, the mean of the responses observed in the field for a given climatic variable value. Since $Y$ is a random discrete variable whose possible values are finite, the best way to estimate the expected mean index value in a given time interval is to use the formula of the expected value for discrete random variables, or a finite case, since the responses are limited to the [32] 7-point class interval:

$$
E[y]=\sum_{k=1}^{n} y_{k} p_{k}
$$

where $y_{k}$ is the possible value, and $p_{k}$ is its respective probability in some independent tests.

In the case of the present study,

$$
I_{\text {mean }}=\sum_{n=1}^{n} I_{k} p_{k}
$$

where $I_{k}$ is the mean index, and $p_{k}$ is the probability estimated by dividing the number of responses to the index by the total number of interviews performed in a given interval.

Subsequently, more than 100 regressions were performed with multiple variables to obtain the appropriate parameters for the various situations examined. Regressions were also tested using absolute humidity rather than relative humidity. This is because collinearity was observed in the results, and the variance inflation factor (VIF) test was used, which, according to Marquardt and Marquardt and Snee [51,52], is used to determine the variables with VIF values exceeding 10, which should be excluded to prevent compromising the model.

Finally, the index was validated with the data obtained in the first field survey conducted in August 2015, and through the uncertainty test for the samples,

$$
\sigma_{I}=\sum_{n=1}^{n}\left(y_{k}-I\right)^{2} p_{k}
$$

where $\sigma_{i}$ is the uncertainty of the mean of the votes obtained through interviews, $y_{k}$ is the $k$ index ( $k=-3$ to 3 ), and $p_{k}$ is the estimated probability of obtaining the $y_{k}$ index.

After the uncertainty calculation, the $t$-test or Student's test was performed as given by the following equation:

$$
T=\frac{I_{\text {mean }}-I_{\text {model }}}{\frac{\sigma}{\sqrt{n}}}
$$

where $I_{\text {mean }}$ is the comfort index obtained by the mean of the votes obtained in the interviews, $I_{\text {model }}$ is the index calculated by the model, $\sigma$ is the uncertainty of the mean of the votes obtained through interviews, and $n$ is the number of samples (number of interviews to obtain the calculated mean). 
The multiple linear regression method is simple and robust, since the linearity assumptions of the data, such as normality (obtained by the measure of obliquity and kurtosis of the distribution) were verified, which were, finally, executed in the process method validation [53].

In order to obtain an even more efficient validation for the developed model, 33\% of the data were used for the comparison between this and the already traditional models in the literature, including Physiologically Equivalent Temperature (PET) [54], Standard Effective Temperature (SET) *, and Predicted Mean Vote (PMV) [30], which had their classes adjusted by Gobo, Galvani and Wollmann [55] for the same climatic situation in Santa Maria.

\section{Results}

We chose to develop a simplified thermal comfort index for winter and summer conditions based on the independent variables including air temperature, relative air humidity, and wind speed. These variables are easily measurable and available in databases from meteorological institutes.

The assumptions of the linear models, as if the predictors are normally distributed and have equal variances, are verified by Asymmetry, Curtosis, and Heteroscedasticity measurements obtained by the GVLMA (Global Validation of Linear Model Assumption) package of the R programming language (Table 4).

Table 4. Validation test of the method.

\begin{tabular}{ccc}
\hline Test & Value & $p$-Value \\
\hline Asymmetry & 0.09089 & 0.76305 \\
Curtosis & 0.59938 & 0.43881 \\
Heteroscedasticity & 1.46280 & 0.22648 \\
\hline
\end{tabular}

The correlation between logistic and linear regression models was $\pm 98 \%$, proving unnecessary the use of two different methods, and therefore, the multiple linear regression model was used. The values of Table 3 show acceptable results, which increase the confidence in the model.

The results revealed a strong positive correlation between the means of the thermal sensation votes and air temperature, with an $R^{2}$ value equal to 0.96 (Figure 6).

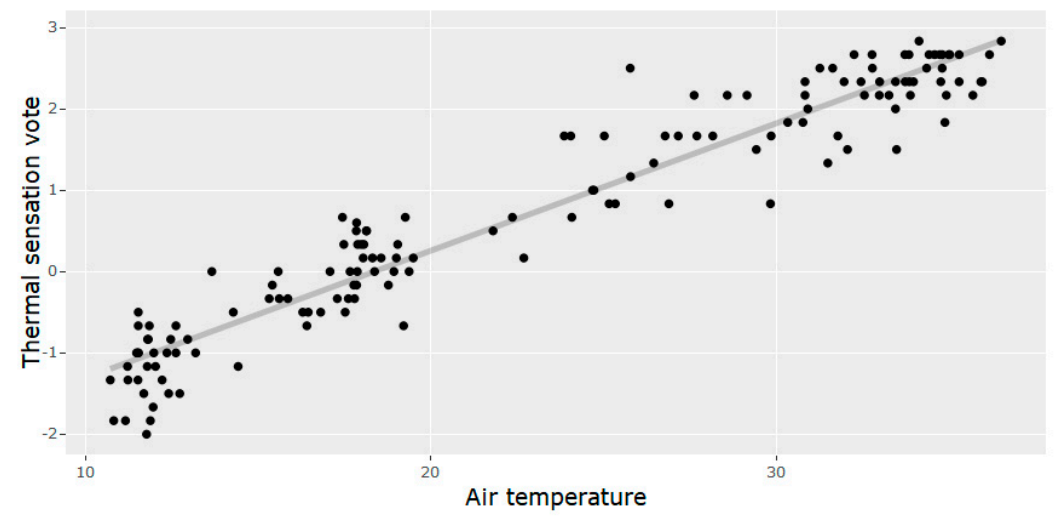

Figure 6. Correlation between thermal sensation vote and air temperature.

The correlation analysis of air temperature with the other variables indicated a strong negative correlation with relative air humidity for both July and January. However, the strong correlation between the variables air temperature and relative air humidity may impair the model results due to internal collinearity.

According to Monteiro et al. [56], when the relative air humidity has a significant negative correlation with air temperature, direct consideration of this information may lead to the false interpretation that higher relative humidity leads to more intense cold sensations. However, relative 
humidity has a strong negative correlation with air temperature, approaching 1 in the most restricted data set observed by the author. Taking into account the fact that the absolute humidity is more or less constant during a given period, higher air temperature results in lower relative humidity. Thus, the correlation obtained for air humidity is largely due to the variation in air temperature [56].

Monteiro et al. [56] add that when considering a larger data set that includes hotter and colder thermal conditions, a longer series of days will have different absolute humidities, leading to different correlations between air temperature and relative humidity. Nevertheless, relative humidity is dependent on air temperature, and therefore, as is observed in the subsequent analyses, it is necessary to consider the absolute humidity for effective testing of the effects of humidity on the subjective thermal sensation responses.

Thus, a new regression was performed for the same parameters, but with the variable absolute humidity ( $g$ of water vapor per $\mathrm{m}^{3}$ of air) replacing relative humidity. However, the results obtained for the absolute humidity variable did not show a considerable statistical improvement, as shown in Table 5, where the significance value of the variable absolute humidity decreased relative to relative humidity, becoming 0.395 (Table 5) compared to the significance level of 0.711 for relative humidity (Table 6).

Table 5. Results of the regression performed with the variable absolute air humidity.

\begin{tabular}{lcccc}
\hline & Coefficient & Standard Error & $t$ & $p$-Value \\
\hline Constant & -2.78739 & 0.12286 & -22.688 & $<2 \times 10^{-16}$ \\
Air temperature & 0.15143 & 0.00484 & 31.290 & $<2 \times 10^{-16}$ \\
Absolute humidity & 0.01018 & 0.01192 & 0.854 & 0.395 \\
Wind speed & -0.41469 & 0.16482 & -2.516 & 0.013 \\
Residual standard error & \multicolumn{5}{c}{0.3889} \\
Multiple $R^{2}$ & 0.9264 & \\
Adjusted $R^{2}$ & \multicolumn{5}{c}{0.9248} \\
F-Statistic & \multicolumn{5}{c}{587.5} \\
Level of significance- $p$ & \multicolumn{5}{c}{$<2 \times 10^{-16}$} \\
\hline
\end{tabular}

Thus, the VIF was calculated for the previously selected variables. As stated by Marquardt [52], variables with VIF values greater than 10 should be excluded; however, the collinear variables do not add any relevant value to the model (Table 5), and values above the threshold established by Marquardt [52] were not observed, so it was decided to keep relative humidity in the construction of the index.

The relative air humidity and the means of thermal sensation votes showed a strong negative correlation, with an $\mathrm{R}^{2}$ value of 0.736 (Figure 7). However, the relative humidity had a weak positive correlation with wind speed, with an $R^{2}$ value of 0.209 . Wind speed had a weak correlation with all the other variables, with the correlation between wind and mean thermal sensation votes being negative, which was also the case between wind speed and air temperature (Figure 8).

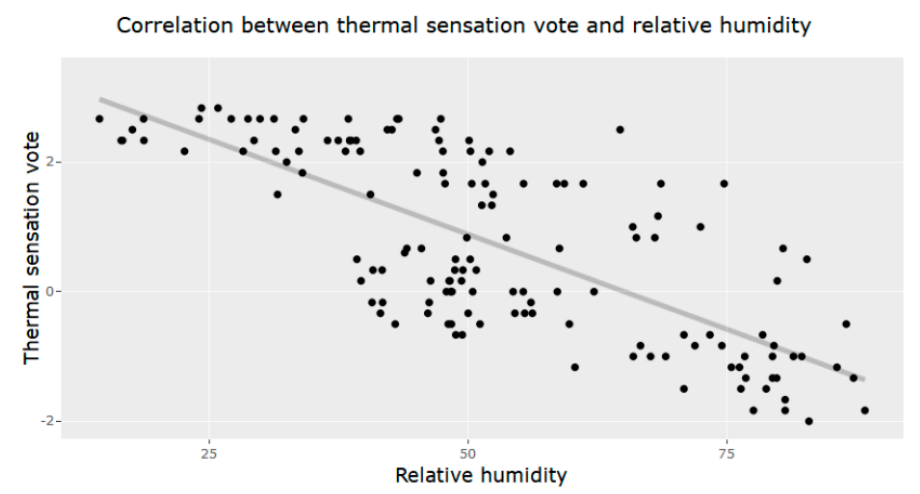

Figure 7. Correlation between the pedestrians' thermal sensation votes and mean relative air humidity in the two analysis periods (January and July 2016). 


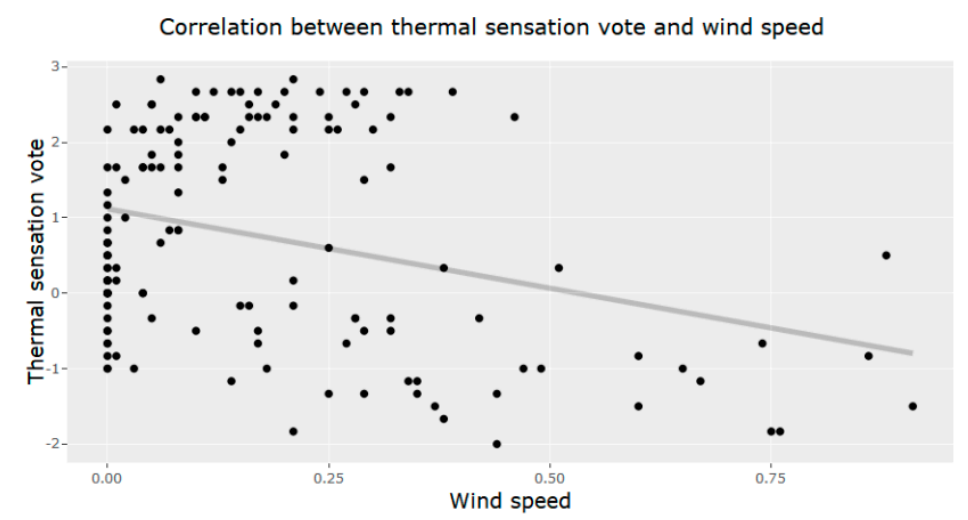

Figure 8. Correlation between the pedestrians' thermal sensation votes and mean wind speed in the two analysis periods (January and July 2016).

The probability density function (PDF) - or density of a continuous random variable-was calculated for the means of the thermal sensation votes of the individuals interviewed during the entire study (winter and summer) as well as for mean air temperature, mean relative humidity and mean wind speed for that period. The PDF is a function that describes the relative probability of these random variables when taking a given value.

Table 5 shows the results of the linear regressions performed for the mean values reached for the conditions surveyed during the study (summer and winter) to obtain the model.

Table 6. Statistical analysis of the constant, three independent variables and variance for the regression performed with the complete series (January and July 2016).

\begin{tabular}{cccccc}
\hline & Coefficient & Standard Error & $\boldsymbol{T}$ & Level of Significance & $\begin{array}{c}\text { Variance Inflation } \\
\text { Factor (VIF) }\end{array}$ \\
\hline Constant & -2.642548 & 0.269316 & -9.812 & $<2 \times 10^{-16}$ & - \\
$\mathrm{T}_{\text {air }}$ & 0.152299 & 0.005831 & 26.118 & $<2 \times 10^{-16}$ & 2.437 \\
$\mathrm{RH}$ & -0.001043 & 0.002811 & -0.371 & 0.71119 & 2.379 \\
$\mathrm{~S}$ & -0.430040 & 0.164042 & -2.622 & 0.00972 & 1.071 \\
& Residual standard error & & 0.389 & \\
& Multiple $\mathrm{R}^{2}$ & & 0.926 & \\
& Adjusted $\mathrm{R}^{2}$ & 0.924 & \\
F-Statistic & & 584.9 & \\
& Level of significance- $p$ & & $<2.2$ & \\
\hline
\end{tabular}

Thus, the model had high multiple $\mathrm{R}^{2}$ and adjusted $\mathrm{R}^{2}$ values of 0.926 and 0.924 , respectively, whereas the statistical test $\mathrm{F}$ showed a high value of 584.9 , which confirms that together the variables contribute to the prediction of the independent variable.

Next, an equation was defined that considers the three independent variables (Tair, RH and S) correlated for the situation survey and the mean value of perceived thermal sensation in each (based on the results of the questionnaires applied in January and July 2016):

$$
B S I=0.1523 \times \text { Tair }-0.0010 \times R H-0.4300 \times S-2.6425
$$

where BSI = Brazilian Subtropical Index, Tair $=$ air temperature $\left({ }^{\circ} \mathrm{C}\right), R H=$ relative humidity $(\%)$, and $S=$ wind speed $(\mathrm{m} / \mathrm{s})$.

The Brazilian Subtropical Index (BSI) is the proposed model, which is defined as a thermal sensation scale based on the mean vote of individuals interviewed during winter and summer using the 7-point scale (Table 7). 
Table 7. Interpretive bands for the Brazilian Subtropical Index (BSI).

\begin{tabular}{cc}
\hline$\leq-3$ & Very cold \\
-2.9 to -2 & Cold \\
-1.9 to -1 & Slightly cold \\
-0.9 to 0.9 & Neither cold nor hot \\
1 to 1.9 & Slightly hot \\
2 to 2.9 & Hot \\
$\geq 3$ & Very hot \\
\hline
\end{tabular}

\section{Validation of the Proposed Empirical Index}

The model was validated using a Student's $t$-test to evaluate the relationship between the comfort index predicted by the BSI model (obtained with data from January and July) and the thermal sensation votes of the interviewees. For this purpose, 857 interviews were obtained from the August 2015 survey and compared to the BSI results for the same period.

The results of the validations are shown in Table 8 and Figure 9.

Table 8. Accuracy score by $t$-test $(p$-value $=0.05)$.

\begin{tabular}{cc}
\hline Days Tested & BSI \\
\hline 5 August 2015 & 0.875 \\
6 August 2015 & 0.812 \\
7 August 2015 & 0.791 \\
\hline
\end{tabular}

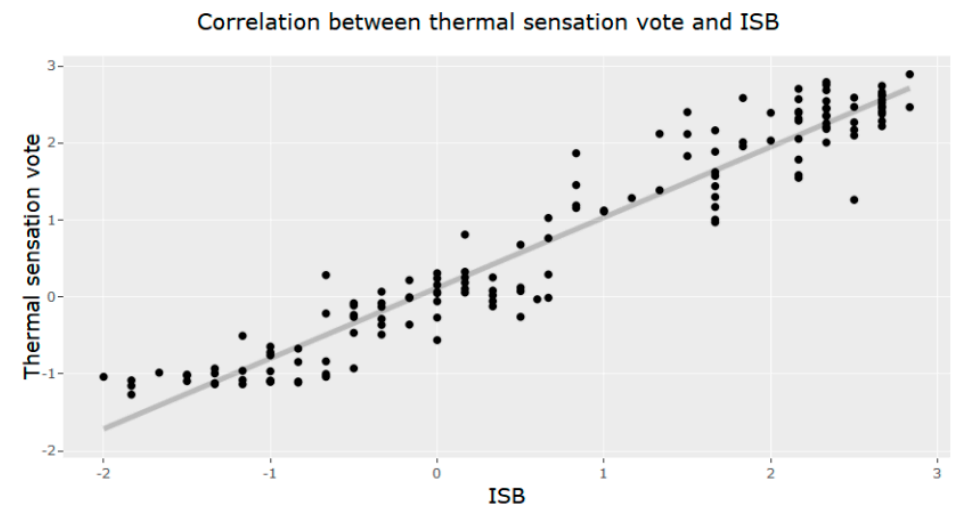

Figure 9. Correlation between the empirical data from interviews collected in August and the model made by the data obtained in January and July: 0.96 .

The hit rate obtained via the validation of the index is $88 \%$ for the first test, $81 \%$ for the second test and 79\% for the third test. These values are higher than those observed by Gobo et al. [54] in a study calibrating the interpretative ranges of PET, SET and PMV indices for Santa Maria, where the authors identified hit rates after the calibration of $69.3 \%$ for the PET, $64.9 \%$ for the SET and $58.7 \%$ for the PMV index.

As observed in the study of Salata et al. [36], the Mediterranean Outdoor Comfort Index (MOCI) presented an adjusted $R^{2}$ value of 0.395 , an $R^{2}$ value of 0.398 , and a Pearson coefficient of 0.631 , whereas the BSI presented an $R^{2}$ value of 0.926 and an adjusted $R^{2}$ value of 0.924 and a higher Pearson coefficient, 0.790 .

Comparing the results obtained during the development and validation of the BSI with those observed by Ruiz and Correa [8], the adjusted $R^{2}$ value of the latter is closer (0.719), with a predictive capacity of $73 \%$, which is very close to that observed in the validation of the BSI.

When comparing the results of the Global Outdoor Comfort Index (GOCI) developed by Golasi et al. [10], an adjusted $\mathrm{R}^{2}$ value of 0.379 and a Pearson coefficient of 0.616 were observed 
for the GOCI, whereas the BSI presented an adjusted $\mathrm{R}^{2}$ value of 0.924 and Pearson coefficient higher than 0.790 , further indicating the efficiency of the BSI.

The BSI hit rates are higher than $50 \%$, and it should be noted that Nikolopoulou and Steemers [57], when analyzing psychological aspects related to thermal sensation, found that climatic variables have a strong influence on thermal sensation, but these explain approximately $50 \%$ of the variation between objective and subjective assessments of comfort.

Of the approximately 165 thermal indices developed to date, only 4 (PET, PMV, Universal Thermal Climate Index (UTCI) and SET *) are widely used in studies of outdoor thermal perception [58]. Thus, a correlation test was performed between the respondents' thermal preference responses in the period used for the BSI validation (August 2015) and the PET, SET * and PMV models calibrated by Gobo, Galvani and Wollmann [54] to Santa Maria. The results are described in Table 9.

Table 9. Correlation between the PET, SET * and PMV models calibrated by Gobo, Galvani and Wollmann (2018) for Santa Maria and the thermal preference of the interviewees.

\begin{tabular}{cc}
\hline Indexes & Correlation \\
\hline Calibrated PET & 0.23 \\
Calibrated SET & 0.14 \\
Calibrated PMV & 0.38 \\
\hline
\end{tabular}

It is important to note that the correlations made between the PET, SET *, PMV, and the thermal preference responses of the interviewees (Table 9) were only for the BSI validation period of August 2015, differing from the period used by Gobo, Galvani and Wollman [55] in the calibration of the mentioned models, where the whole series of August of 2015, January and July of 2016 was used.

The low efficiency of the PET, SET * and PMV indices for the analyzed period can be explained in part by the large size of the comfort range of these indices as calibrated by Gobo, Galvani and Wollman [54] for the study area, featuring $16^{\circ} \mathrm{C}-24^{\circ} \mathrm{C}$ for PET, $17^{\circ} \mathrm{C}-23^{\circ} \mathrm{C}$ for the SET and $-1-0.8$ for the PMV. Potchter et al. [58], when analyzing a work done with PET in the Cfa climate [45], signals for the acceptance of the comfort range of $87 \%$ of the case studies between $24^{\circ} \mathrm{C}$ and $27^{\circ} \mathrm{C}$ and up to $94 \%$ of the cases between $25^{\circ} \mathrm{C}-26^{\circ} \mathrm{C}$, which considerably limits the comfort range for these indexes. Therefore, the validation of the BSI presented greater efficiency when compared to the other indexes commonly used in studies appearing in the literature.

\section{Conclusions}

The index obtained by means of multiple linear regressions presented high statistic values that did not reveal any anomalous behaviors that indicated inadequacy of the chosen model. The multiple linear regression model presented considerable results when compared to the other regression models, which increased confidence in the use of this model. The VIF demonstrated that the collinear variables do not add any relevant value to the model, with no values above the limit established by Marquardt [52] being found.

The proposal of the Brazilian Subtropical Index (BSI) provides a simple and easy-to-apply model with temperature, relative air humidity, and wind velocity as input variables. Therefore, it accounts for meteorological attributes commonly measurable in conventional and automatic surface meteorological stations.

The results expressed the perception of the interviewees regarding comfort and thermal discomfort for the locality of Santa Maria, a subtropical climate region in southern Brazil. A high rate of model accuracy, with a multiple $\mathrm{R}^{2}$ and adjusted $\mathrm{R}^{2}$ of 0.926 and 0.924 respectively, and a high statistical $\mathrm{F}$ with value of 584.9, confirmed that, together, the modeled variables contributed to the prediction of the independent variable. 
Thus, like any statistical model, the index proposed here has limitations, and its effectiveness in situations different from those analyzed should be explored based on more detailed studies and with a longer observation times.

Finally, BSI validation has proved to be effective. With hit rates higher than $80 \%$, these values are higher than those observed for the PET, SET and PMV indices for Santa Maria, which indicates the efficiency and reliability of the model.

Author Contributions: J.P.A.G. designed the research; J.P.A.G. and E.G. carried out the measurements; J.P.A.G. and FARIA, M.R. led the analyses, and statistical models; F.L.T.G., L.M.M. and E.G. contributed with research materials and equipment; J.P.A.G. led the writing, with major input from all other authors.

Funding: This research was funded by Conselho Nacional de Desenvolvimento Científico e Tecnológico (CNPq).

Acknowledgments: The authors of this research thank the collaborators: Cássio Arthur Wollmann, coordinator of the Laboratory of Environmental and Subtropical Climatology (LaCAS) of the Federal University of Santa Maria (UFSM), and their students, who assisted in the development of the fieldwork of this research, and to the residents of the city of Santa Maria, Rio Grande do Sul, Brazil.

Conflicts of Interest: The authors declare no conflicts of interest.

\section{Nomenclature}

$\begin{array}{llll}\text { BSI } & \text { Brazilian Subtropical Index } & \text { PMV } & \text { Predicted Mean Vote } \\ \text { SET } & \text { Standard Effective Temperature } & \mathrm{T}_{\text {air }} & \text { Air Temperature } \\ \text { AWS } & \text { Automatic Weather Station } & \text { RH } & \text { Relative Humidity } \\ \text { VIF } & \text { Variance Inflation Factor } & \mathrm{S} & \text { Wind Speed } \\ \text { PDF } & \text { Probability Density Function } & \text { UTCI } & \text { Universal Thermal Climate Index } \\ \text { GVLMA } & \text { Global Validation of Linear Model Assumption } & \text { GOCI } & \text { Global Outdoor Comfort Index } \\ \text { PET } & \text { Physiologically Equivalent Temperature } & \text { MOCI } & \text { Mediterranean Outdoor Comfort Index } \\ \text { Cfa } & \text { Humid subtropical climate } & & \end{array}$

\section{References}

1. Höppe, P. Different aspects of assessing indoor and outdoor thermal comfort. Energy Build. 2002, 34, 661-665. [CrossRef]

2. Monteiro, L.M.; Alucci, M.P. Questões teóricas de conforto térmico em espaços abertos: Consideração histórica, discussão do estado da arte e proposição de classificação de modelos. Ambient. Construído 2007, 7, $43-58$.

3. Bröde, P.; Fiala, D.; Blazejczyk, K.; Holmér, I.; Jendritzky, G.; Kampmann, B.; Tinz, B.; Havenith, G. Deriving the operational procedure for the Universal Thermal Climate Index (UTCI). Int. J. Biometeorol. 2012. [CrossRef] [PubMed]

4. Rossi, F.A.; Krüger, E.L.; Bröde, P. Definição de faixas de conforto e desconforto térmico para espaços abertos em Curitiba, PR, com o índice UTCI. Ambient. Construído 2012, 12, 41-59. [CrossRef]

5. Pantavou, K.; Theoharatos, G.; Santamouris, M.; Asimakopoulos, D. Outdoor thermal sensation of pedestrians in a Mediterranean climate and a comparison with UTCI. Build. Environ. 2013, 66, 82-95. [CrossRef]

6. Lai, D.; Guo, D.; Hou, Y.; Lin, C.; Chen, Q. Studies of outdoor thermal comfort in northern China. Build. Environ. 2014, 77, 110-118. [CrossRef]

7. Giannaros, T.M.; Lagouvardos, K.; Kotroni, V.; Matzarakis, A. Operational forecasting of human-biometeorological conditions. Int. J. Biometeorol. 2018, 62, 1339-1343. [CrossRef] [PubMed]

8. Ruiz, M.A.; Correa, E.N. Adaptive model for outdoor thermal comfort assessment in an Oasis city of arid climate. Build. Environ. 2015, 85, 40-51. [CrossRef]

9. Manu, S.; Shukla, Y.; Rawal, R.; Thomas, L.E.; de Dear, R. Corrigendum to "Field studies of thermal comfort across multiple climate zones for the subcontinent: India model for adaptive comfort (IMAC)" [Building and Environment 98 (2016) 55-70](S0360132315302171)(10.1016/j.buildenv.2015.12.019). Build. Environ. 2016, 106, 422-426. [CrossRef] 
10. Golasi, I.; Salata, F.; de Lieto Vollaro, E.; Coppi, M. Complying with the demand of standardization in outdoor thermal comfort: A first approach to the Global Outdoor Comfort Index (GOCI). Build. Environ. 2018, 130, 104-119. [CrossRef]

11. Zambrano, L.; Malafaia, C.; Bastos, L. Thermal comfort evaluation in outdoor space of tropical humid climate. In Proceedings of the 23rd Conference on Passive and Low Energy Architecture, Geneva, Switzerland, 6-8 September 2006.

12. Rossi, F.A.; Krüger, E.L.; Guimarães, I.A. Modelo preditivo de sensação térmica em espacos abertos em Curitiba, PR. RA'E GA-O Espaço Geográfico em Análise 2013, 209-238. [CrossRef]

13. Gulyás, Á.; Unger, J.; Matzarakis, A. Assessment of the microclimatic and human comfort conditions in a complex urban environment: Modelling and measurements. Build. Environ. 2006. [CrossRef]

14. Cheng, V.; Ng, E. Thermal Comfort in Urban Open Spaces for Hong Kong. Archit. Sci. Rev. 2006. [CrossRef]

15. Spagnolo, J.; de Dear, R. A field study of thermal comfort in outdoor and semi-outdoor environments in subtropical Sydney Australia. Build. Environ. 2003, 38, 721-738. [CrossRef]

16. Lin, T.P.; de Dear, R.; Hwang, R.L. Effect of thermal adaptation on seasonal outdoor thermal comfort. Int. J. Climatol. 2011, 31, 302-312. [CrossRef]

17. Farajzadeh, H.; Saligheh, M.; Alijani, B.; Matzarakis, A. Comparison of selected thermal indices in the northwest of Iran. Nat. Environ. Chang. 2015, 1, 1-20.

18. Kántor, N.; Kovács, A.; Takács, Á. Seasonal differences in the subjective assessment of outdoor thermal conditions and the impact of analysis techniques on the obtained results. Int. J. Biometeorol. 2016. [CrossRef] [PubMed]

19. Gobo, J.P.A.; Alves, R.R.; Silveira, T.S.; de Souza Onça, D.; Monteiro, L.M.; Wollmann, C.A.; Galvani, E. The influence of regional wind on thermal sensation of walking in open urban spaces: Case study of the North Wind in Santa Maria-RS. RA'E GA-O Espaço Geográfico em Análise 2017, 40. [CrossRef]

20. Nasir, R.A.; Ahmad, S.S.; Ahmed, A.Z. Psychological Adaptation of Outdoor Thermal Comfort in Shaded Green Spaces in Malaysia. Procedia. Soc. Behav. Sci. 2012, 68, 865-878. [CrossRef]

21. Chen, L.; $\mathrm{Ng}$, E. Outdoor thermal comfort and outdoor activities: A review of research in the past decade. Cities 2012, 29, 118-125. [CrossRef]

22. Yang, W.; Wong, N.H.; Jusuf, S.K. Thermal comfort in outdoor urban spaces in Singapore. Build. Environ. 2013, 59, 426-435. [CrossRef]

23. Villadiego, K.; Velay-Dabat, M.A. Outdoor thermal comfort in a hot and humid climate of Colombia: Afield study in Barranquilla. Build. Environ. 2014, 75, 142-152. [CrossRef]

24. Hirashima, S.Q.; Katzschner, A.; Ferreira, D.G.; de Assis, E.S.; Katzschner, L. Thermal comfort comparison and evaluation in different climates. Urban Clim. 2018, 23, 219-230. [CrossRef]

25. Krüger, E.; Rossi, F.; Drach, P. Calibration of the physiological equivalent temperature index for three different climatic regions. Int. J. Biometeorol. 2017, 61, 1323-1336. [CrossRef] [PubMed]

26. Blazejczyk, K.; Epstein, Y.; Jendritzky, G.; Staiger, H.; Tinz, B. Comparison of UTCI to selected thermal indices. Int. J. Biometeorol. 2012, 56, 515-535. [CrossRef] [PubMed]

27. Johansson, E.; Thorsson, S.; Emmanuel, R.; Krüger, E. Instruments and methods in outdoor thermal comfort studies - The need for standardization. Urban Clim. 2014. [CrossRef]

28. Gagge, A.P. A Standard Predictive Index of Human Response to the Thermal Environment. ASHRAE Trans. 1986. Available online: https:/ / www.scopus.com/home.uri (accessed on 6 June 2017).

29. Pickup, J.; de Dear, R. An outdoor thermal comfort index (OUT_SET*)-part I-the model and its assumptions. In Biometeorology and Urban Climatology at the Turn of the Millenium, Proceedings of the Conference ICB-ICUC'99, Sydney, Australia, 8-12 November 1999; WCASP-50; WMO: Geneva, Switzerland, 1999; pp. 279-283.

30. Fanger, P.O. Thermal Comfort, Analysis and Application in Environmental Engineering; Copenhagen Danish Tech. Press: Copenhagen, Denmark, 1970.

31. International Organnization for Standardization (ISO). ISO 7730 Ergonomics of the thermal environment Analytical determination and interpretation of thermal comfort using calculation of the PMV and PPD indices and local thermal comfort criteria. Management 2005. [CrossRef]

32. ASHRAE Standard 55-2017 Thermal Environmental Conditions for Human Occupancy; Ashrae: Atlanta, GA, USA, 2017; ISBN 1041-2336. 
33. Salata, F.; Golasi, I.; de Lieto Vollaro, R.; de Lieto Vollaro, A. Urban microclimate and outdoor thermal comfort. A proper procedure to fit ENVI-met simulation outputs to experimental data. Sustain. Cities Soc. 2016, 26, 318-343. [CrossRef]

34. Nikolopoulou, M.; Lykoudis, S.; Kikira, M. Thermal comfort in outdoor spaces: Field studies in Greece. In Proceedings of the 5th International Conference on Urban Climate, Lotz, Poland, 1-5 September 2003; Volume 2, pp. 91-94.

35. Cheng, Y.; Niu, J.; Gao, N. Thermal comfort models: A review and numerical investigation. Build. Environ. 2012, 47, 13-22. [CrossRef]

36. Salata, F.; Golasi, I.; de Lieto Vollaro, R.; de Lieto Vollaro, A. Outdoor thermal comfort in the Mediterranean area. A transversal study in Rome, Italy. Build. Environ. 2016, 96, 46-61. [CrossRef]

37. Emmanuel, R. Thermal comfort implications of urbanization in a warm-humid city: The Colombo Metropolitan Region (CMR), Sri Lanka. Build. Environ. 2005. [CrossRef]

38. Coccolo, S.; Kämpf, J.; Scartezzini, J.L.; Pearlmutter, D. Outdoor human comfort and thermal stress: A comprehensive review on models and standards. Urban Clim. 2016, 18, 33-57. [CrossRef]

39. Pantavou, K.; Lykoudis, S.; Nikolopoulou, M.; Tsiros, I.X. Thermal sensation and climate: A comparison of UTCI and PET thresholds in different climates. Int. J. Biometeorol. 2018, 1-14. [CrossRef] [PubMed]

40. Krüger, E.L.; Tamura, C.A.; Bröde, P.; Schweiker, M.; Wagner, A. Short- and long-term acclimatization in outdoor spaces: Exposure time, seasonal and heatwave adaptation effects. Build. Environ. 2017, 116, 17-29. [CrossRef]

41. Maras, I.; Schmidt, T.; Paas, B.; Ziefle, M.; Schneider, C. The impact of human-biometeorological factors on perceived thermal comfort in urban public places. Meteorol. Zeitschrift 2016. [CrossRef]

42. da Silveira Hirashima, S.Q.; de Assis, E.S.; Nikolopoulou, M. Daytime thermal comfort in urban spaces: A field study in Brazil. Build. Environ. 2016, 107, 245-253. [CrossRef]

43. Barry, R.G.; Chorley, R.J. Atmosphere, Weather and Climate, 8th ed.; Routledge: London, UK, 2003; ISBN 0203428234.

44. Alvares, C.A.; Stape, J.L.; Sentelhas, P.C.; de Moraes Gonçalves, J.L.; Sparovek, G. Köppen's climate classification map for Brazil. Meteorol. Zeitschrift 2013, 22, 711-728. [CrossRef]

45. Köppen, W. Das geographisca System der Klimate; Handbuch der Klimatologie: Berlin, Germany, 1936.

46. IBGE Censo 2010. Available online: https:/ / censo2010.ibge.gov.br (accessed on 13 July 2018).

47. Standard, I. ISO 7726 Ergonomics of the Thermal Environment-Instruments for Measuring Physical Quantities; International Organnization for Standardization: Geneva, Switzerland, 1998.

48. Nikolopoulou, M.; Baker, N.; Steemers, K. Thermal comfort in outdoor urban spaces: Understanding the Human parameter. Sol. Energy 2001, 70, 227-235. [CrossRef]

49. International Organnization for Standardization (ISO). ISO 9920 Ergonomics of the Thermal EnvironmentEstimation of Thermal Insulation and Water Vapour Resistance of a Clothing Ensemble; ISO: Geneva, Switzerland, 2007.

50. International Organnization for Standardization (ISO). ISO 8996 Ergonomics of the Thermal EnvironmentDetermination of Metabolic Rate; ISO: Geneva, Switzerland, Management 2004. [CrossRef]

51. Marquardt, D.W.; Snee, R.D. Ridge regression in practice. Am. Stat. 1975. [CrossRef]

52. Marquardt, D.W. Generalized Inverses, Ridge Regression, Biased Linear Estimation, and Nonlinear Estimation. Technometrics 1970. [CrossRef]

53. Tabachnick, B.G.; Fidell, L.S. Using Multivariate Statistics, 6th ed.; New York Harper Row: Boston, MA, USA, 2012.

54. Höppe, P. The physiological equivalent temperature-A universal index for the biometeorological assessment of the thermal environment. Int. J. Biometeorol. 1999, 43, 71-75. [CrossRef] [PubMed]

55. Gobo, J.P.A.; Galvani, E.; Wollmann, C.A. Subjective Human Perception of Open Urban Spaces in the Brazilian Subtropical Climate: A First Approach. Climate 2018, 6, 24. [CrossRef]

56. Monteiro, L.M. Modelos Preditivos de Conforto Térmico: Quantificação de Relações Entre Variáveis Microclimáticas e de Sensação Térmica Para Avaliação e Projeto de Espaços Abertos. Ph.D. Thesis, School of Architecture and Urbanism of University of Sao Paulo, Sao Paulo, Brazil, 2008. [CrossRef] 
57. Nikolopoulou, M.; Steemers, K. Thermal comfort and psychological adaptation as a guide for designing urban spaces. Energy Build. 2003, 35, 95-101. [CrossRef]

58. Potchter, O.; Cohen, P.; Lin, T.P.; Matzarakis, A. Outdoor human thermal perception in various climates: A comprehensive review of approaches, methods and quantification. Sci. Total Environ. 2018, 631-632, 390-406. [CrossRef] [PubMed] 